\title{
Presentation and management of classical urea cycle disorders: lessons from our experience
}

\section{Klasik üre döngüsü bozuklukları hastalıklarının klinik ve hasta yönetimi konusunda yaşadıklarımızdan öğrendiklerimiz}

\author{
Sema KALKAN UÇAR ${ }^{1}$, Ebru CANDA ${ }^{1}$, Melis KÖSE ${ }^{4}$, Mehtap KAĞINICI ${ }^{4}$, Özge ALTUN KÖROĞLU², \\ Şebnem ÇALKAVUR ${ }^{5}$, Sara HABİF ${ }^{3}$, Mahmut ÇOKER ${ }^{1}$
}

${ }^{I}$ Ege Üniversitesi Tıp Fakültesi, Çocuk Sağlı̆̆ı ve Hastalıkları Anabilim Dalı, Metabolizma ve Beslenme Bilim Dalı, İzmir

${ }^{2}$ Ege Üniversitesi Tıp Fakültesi, Çocuk Sağlığı ve Hastalıkları Anabilim Dalı, Neonatoloji Bilim Dalı, İzmir

${ }^{3}$ Ege Üniversitesi Tip Fakültesi, Biyokimya Anabilim Dalı, İzmir

${ }^{4}$ İzmir Dr. Behçet Uz Çocuk Hastalıkları ve Cerrahisi Ĕ̆itim ve Araştırma Hastanesi, Çocuk Sağlı̆̆ı ve Hastalıkları, Çocuk Metabolizma ve Beslenme, İzmir

${ }^{5}$ İzmir Dr. Behçet Uz Çocuk Hastalıkları ve Cerrahisi Ĕgitim ve Araştırma Hastanesi Çocuk Să̆lı̆̆ı ve Hastalıkları, Neonatoloji Kliniği, İzmir

\section{ABSTRACT}

\begin{abstract}
Objective: The urea cycle disorders (UCD) are inherited deficiencies of the enzymes or transport molecules involved in the cellular excretion of excess ammonia produced during protein metabolism. The aim of this study was to evaluate the clinical characteristics and long-term outcome of pediatric patients with UCD seen during childhood.

Methods: Clinical characteristics in 13 patients with classical UCD (carbamoyl phosphate synthetase I deficiency $(n=4)$, argininosuccinate lyase deficiency $(n=4)$, argininosuccinate synthetase deficiency $(n=3)$, arginase deficiency $(n=1)$, and ornithine transcarbamylase deficiency $(n=1)$ ) were defined. The term "neonatal-onset" UCD was used if symptoms occurred within 28 days of life, and "late-onset" if symptoms started after that period.

Results: The majority of patients $(n=9)$ presented with acute metabolic crisis during newborn period. Core clinical phenotype in neonatal-onset UCD included sepsis-like neonatal crisis revealed in patients within 28 days after birth, whereas mental retardation was predominant peculiarity in late-onset UCD emerging more than 28 days after birth. Vomiting and hypotonia were frequently reported in neonatalonset UCD, and epilepsy with/without movement disorder was found in late-onset UCD patients. For patients with neonatal-onset UCD hyperammonemia was more severe at first diagnosis of the disease, and remained near upper limits of normal during the follow-up period. However, hyperammonemia and metabolic crisis have been reported lomber spinal stenoz frequently in symptomatic patients. A cardinal principal of UCD in acute and long-term management of UCD. Despite these evolving treatment opportunities, still higher mortality rates were found in neonatal-onset UCD (44\% (4/9)).

Conclusion: Neonatal-onset UCD were generally presents itself as acute onset hyperammonemia during the newborn period. However, neurological manifestations were reportedly more diagnostic in the lateonset UCD. It has been concluded that the basic principles of diagnosis and treatment need to be reorganized to improve recognition and outcome in these diseases.
\end{abstract}

Key words: Ürea cycle disorders, neonatal-onset, late-onset

$\ddot{\mathbf{O Z Z}}$

Amaç: Doğuştan metabolik hastalıklardan olan üre döngüsü hastalıkları (ÜDH), proteinlerin yıkımı sonucu oluşan amonyağın hücresel atılımında görevli enzim ve taşıyıcı moleküllerinin eksikliği sonucu oluşmaktadır. Bu çalışmanın amacı, çocukluk çağında görülen ÜDH klinik özelliklerini ve uzun dönem izlem sonuçlarını değerlendirmektir.

Yöntemler: Klasik UDH (Karbamoil fosfat sentetaz I eksikliği (n=4), Arjininosüksinat liyaz eksikliği $(n=4)$, Arjninosüksinat sentetaz eksikliği $(n=3)$, Arjinaz eksikliği eksikliği $(n=1)$, Ornitin transkarbamilaz eksikliği $(\mathbf{n}=1)$ ) olan 13 hastanın klinik özellikleri belirlenmiştir. Semptomların 28 günden küçük hastalarda ortaya çıkması durumunda yenidoğan-başlangıçlı Ü̉H, 28 günden sonra ortaya çıkan ÜDH için geç-başlangıçlı sözü kullanılmıştır.

Bulgular: Hastaların büyük bir ç.ğgunluğu $(n=9)$ yenidoğan döneminde akut metabolik kriz ile ortaya çımıştır. Yenidoğan-başlangıçl ÜDH sepsis benzeri bir tablo ile kendilerini ortaya koyarken, geçbaslangıch olanlarda ise mental retardasyon ön planda saptanmıstır. Kusma ve hipotoni yenidoğan başlangıçı hastalarda bildirilirken, hareket bozukluğun eşlik ettiği veya etmediği epilepsi geç başlangıçlı ÜDH rapor edilmiştir. Yenidoğan-başlangıçlı ÜDH hiperamoniyemi hastalığın ilk tanısında oldukça yüksek olmakla birlikte, izlem süresinde üst sınırlara yakın olma eğilimini korumuştur. Buna karşın semptomlu gec baslangych hastalarda metabolik kriz ve hiperamonyemi daha az bildirilmistir. ÜDH akut ve kronik tedavisinde protein kısıtlı yüksek enerjili diyet ve azot "toplayıcı" ilaçların birlikte verilmiştir. Gelişen tedavi olanaklarına rağmen, yenidoğan-başlangıçı ÜDH da hala ölüm oranı oldukça yüksek bulunmuştur (44\% (4/9)).

Sonuç: Yenidoğan başlangıçı ÜDH genellikle yenidoğan döneminde hiperamoniyemi ile kendini ortaya koymuştur. Geç-başlangıçı ÜDH da nörolojik bulgulardan tanıya gitmek daha sık bildirilmiştir. Bu hastahıların tanınması ve izlem sonuçlarının iyileştirilmesi amacı ile temel tanı ve tedavi prensiplerinin güncellenip yeniden yapılandırılması gerektiği sonucuna varılmıştır.

Anahtar kelimeler: Üre döngüsü bozuklukları, yenidoğan-başlangıçlı, geç-başlangıçlı
Alındığı tarih: 07.02 .2016

Kabul tarihi: 24.03 .2016

Yazışma adresi: Doç. Dr. Sema Kalkan Uçar, Ege Üniversitesi, Çocuk Sağlığı ve Hastalıkları, 35100 Bornova / İzmir

e-mail: semakalkan@hotmail.com 


\section{INTRODUCTION}

Urea cycle disorders (UCD) are among the most common inborn errors of metabolism with cumulative incidence of 1:8.000 (1). They are group of inborn errors of metabolism in which detoxification of ammonia via Krebs-Henseleit or urea cycle is impaired.

Principally, the urea cycle is composed of five primary enzymes, two transporters, and one cofactor producer designed to rid the body of nitrogenous waste. In order of flow through the pathway, they are carbamyl phosphate synthetase 1, ornithine transcarbamylase, argininosuccinic acid synthetase, argininosuccinic acid lyase, and arginase; the transporters are ornithine mitochondrial 1 and citrin; the cofactor produce is $\mathrm{N}$-acetyl glutamate synthetase. The classical disorders of urea formation generally involve one of the five enzymes (carbamyl phosphate synthetase 1 deficiency (CPS1D), ornithine transcarbamylase deficiency (OTCD), argininosuccinic acid synthetase deficiency (ASSD), argininosuccinic acid lyase deficiency (ASLD), and arginase deficiency (ARGD)) or cofactor producer. A defect in any one of these proteins except arginase leads to an increase in serum ammonia, which at sustained elevated levels, causes cerebral edema, and irreversible brain damage. Arginase deficiency is only rarely associated with abnormally increased levels of ammonia. Instead, the prolonged elevation of blood arginine leads to growth retardation, plateau and eventual loss of cognitive and motor milestones, and severe mental retardation ${ }^{(2,3)}$.

This article presents the neonatal and late presentation of UCD recognized/referred and followed up by our center. The similarities in presentation and history will be emphasized with aim to provide clues for recognizing patients in similar situation. The paper also outlines an approach to diagnosis and management of hyperammonemia and UCD in newborn period and beyond.

\section{MATERIAL and METODS}

The study was designed as retrospective, observational study, based on our patients' hospital records. We reviewed medical records of thirteen patients with a diagnosis of classical (enzyme deficient) UCD between 2006 and 2016. Types of UCD (neonatal-onset/lateonset), diagnostic method, clinical course, treatment and outcome of UCD were the main topics of investigations. Patients with other genetic defects of ammonia detoxification (such as citrullinemia type II, hyperammonemiahyperornithinemia-homocitrullinuria, glutamine synthetase deficiency) were not enrolled. According to the age of onset of the disease the patients were divided to neonatal-( postnatal $\leq 28$ days) and late-onset (postnatal $>28$ days) UCD groups. The information about compliance of the patients was collected based on the number of their regular outpatient visits and completion of requested 3 days of diet history.

\section{RESULTS}

\section{Patients}

Data from 13 patients with classical UCD diagnosis were collected. The distribution of the patients according to diagnosis of UCD subgroups was given in Figure 1. The most common disorders were CPS1D and ASLD.

\section{Distribution of diagnosis}

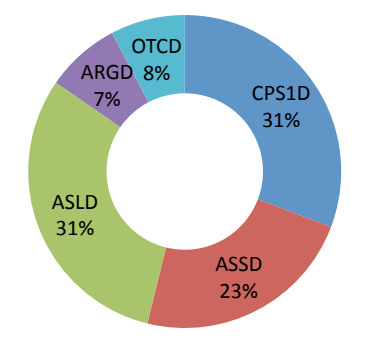

Figure 1. Distribution of diagnosis according to the enzyme deficit.

Abbreviations:

ARGD: Arginase deficiency

ASLD: Arininosuccinate lyase deficiency

ASSD: Argininosuccinate synthetase deficiency

CPS1D: Carbamoyl phosphate synthetase I deficiency

OTCD: Ornithine transcarbamylase deficiency 
The patients' age at the time of data collection ranged from 6 months to 23 years with a mean age of $5.9 \pm 7.2$ years and median age of 3.5 years.

\section{Diagnosis}

All of the patients were diagnosed based on their symptoms. Of them $9(69 \%)$ were presented during the newborn period, and $4(31 \%)$ had a late presentation. Except one, all of neonatal patients had symptoms during the first week of life (median day for presentation was third day of life). The distribution of presentation time of the neonatal onset UCD patients was shown in Figure 2. Of four late presented UCD patients, three was diagnosed during the first three years after birth, and the oldest one diagnosed at the age of 19 years. The diagnoses were made based on amino acid levels and then genetically confirmed. In two patients with neonatal-onset UCD (ASLD) and one late-onset UCD (ARGD) elevated argininosuccinic acid and arginine, respectively were accepted as diagnostic markers in combination with clinical clues of the diseases.

\section{Genetic}

From all 13 patients, 10 (77\%) had genetic testing performed. The consanguinity was present in $9(69 \%)$ of the 13 patients, the couples were first cousins in all of them. Additionally, family history was positive in five families; one being non-consanguineous.

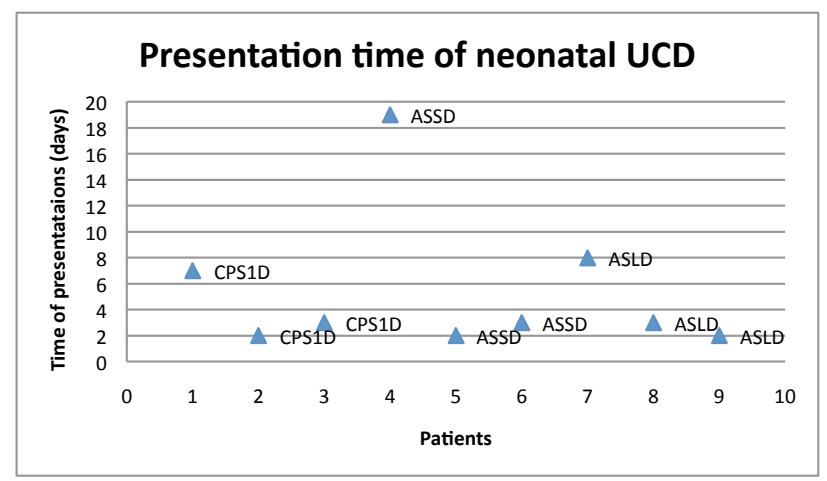

Figure 2. Age distribution of neonatal patients according to the time of diagnosis.

\section{Abbreviations:}

ARGD: Arginase deficiency

ASLD: Arininosuccinate lyase deficiency

ASSD: Argininosuccinate synthetase deficiency

CPS1D: Carbamoyl phosphate synthetase I deficiency

OTCD: Ornithine transcarbamylase deficiency

Table 1. Characteristics of the patients with neonatal and late onset UCD.

\begin{tabular}{|c|c|c|c|c|c|c|c|c|c|}
\hline $\begin{array}{l}\text { Patients } \\
\text { (Gender) }\end{array}$ & Diagnosis & $\begin{array}{l}\text { Consanguinity/ } \\
\text { Family history }\end{array}$ & $\begin{array}{c}\text { Gestational age } \\
\text { (weeks)/Birth } \\
\text { weight (grams) }\end{array}$ & $\begin{array}{l}\text { Age at first } \\
\text { symptoms }\end{array}$ & $\begin{array}{l}\text { Presenting } \\
\text { symptoms }\end{array}$ & $\begin{array}{l}\text { Ammonia level } \\
\text { (at presentation, } \\
\text { range during } \\
\text { follow-up) } \mu \mathrm{mol} / \mathrm{L}\end{array}$ & $\begin{array}{c}\text { Neurological } \\
\text { manifestations } \\
\text { on follow-up }\end{array}$ & $\begin{array}{c}\text { Genetic } \\
\text { mutation } \\
\text { (Gene-Mutation } \\
\text { type) }\end{array}$ & $\begin{array}{c}\text { Outcome/ } \\
\text { Current } \\
\text { age }\end{array}$ \\
\hline
\end{tabular}

\begin{tabular}{|c|c|c|c|c|c|c|c|c|c|}
\hline \multicolumn{10}{|c|}{ Neonatal- onset UCD } \\
\hline $1(f)$ & CPS1D & c.m./f.h. & $38 \mathrm{w}-3700 \mathrm{gr}$ & $7 \mathrm{~d}$ & s.l.a., vomiting & $588(101-588)$ & $\begin{array}{c}\text { Seizures, } \\
\text { Hydrocephaly }\end{array}$ & CPS1, HoM & D: $3 y$ \\
\hline $2(f)$ & CPS 1D & c.m./f.h. & $38 \mathrm{w}-2890 \mathrm{gr}$ & $2 d$ & s.l.a. & $1983(233-320)$ & Hypotonia & CPS1, HoM & D: $6 \mathrm{~d}$ \\
\hline $3(f)$ & CPS1D & c.m. & $40 w-2650 \mathrm{gr}$ & $3 \mathrm{~d}$ & s.l.a. vomiting & $4888(258-6056)$ & Hypotonia & CPS1, HoM & D: $5 \mathrm{~d}$ \\
\hline $4(f)$ & ASSD & c.m. & $36 w-1990 \operatorname{gr}(t)$ & $19 \mathrm{~d}$ & s.l.a. vomiting & 749 (17-749) & $\begin{array}{c}\text { Seizures, } \\
\text { MR (moderate) }\end{array}$ & ASS1, HoM & S: 3 y \\
\hline $5(f)$ & ASSD & c.m./f.h. & $39 w-3340$ gr & $2 d$ & s.l.a. & $485(90-970)$ & Hypotonia & ASS1, HoM & D: $7 \mathrm{~d}$ \\
\hline $6(\mathrm{~m})$ & ASSD & c.m. & $38 w-3600$ gr & $3 \mathrm{~d}$ & s.l.a. vomiting & $2434(1013-2834)$ & Hypotonia & ASS1, HoM & D: $6 \mathrm{~d}$ \\
\hline $7(\mathrm{~m})$ & ASLD & $(-)$ & $38 w-2820$ gr & $3 \mathrm{~d}$ & s.l.a. & $759(36-520)$ & No & NA & $\mathrm{S}: 11 \mathrm{mo}$ \\
\hline $8(f)$ & ASLD & c.m. & $38 w-3100 \mathrm{gr}$ & $3 \mathrm{~d}$ & s.l.a. & $8984(23-856)$ & Seizures & NA & $\mathrm{S}: 6 \mathrm{mo}$ \\
\hline $9(f)$ & ASLD & c.m. & $38 \mathrm{w}-3050 \mathrm{gr}$ & $2 d$ & s.l.a. & $1031(17-58)$ & MR (severe) & ASL, HoM & $\mathrm{S}: 5 \mathrm{y}$ \\
\hline \multicolumn{10}{|c|}{ Late- onset UCD } \\
\hline $10(\mathrm{~m})$ & OTCD & $(-) / f . h$. & $38 w-2600$ gr & $1 \mathrm{y}$ & vomiting & $159(78-160)$ & MR (mild) & OTC, HoM & S: 3 y \\
\hline $11(f)$ & ASLD & $(-)$ & $38 \mathrm{w}-3000 \mathrm{gr}$ & $1 \mathrm{y}$ & sepsis & $150(24-250)$ & MR (mild) & ASL, HoM & S: 8 y \\
\hline $12(f)$ & ARGD & c.m./f.h. & $38 \mathrm{w}-3500 \mathrm{gr}$ & $3 y$ & seizure-spasticity & $35(23-67)$ & $\begin{array}{c}\text { Spasticity } \\
\text { MR (moderate) }\end{array}$ & NA & S: 4 y \\
\hline $13(f)$ & CPS 1D & $(-)$ & $40 w-3750 \mathrm{gr}$ & $19 \mathrm{y}$ & $\begin{array}{l}\text { encephalopathy } \\
\text { (after valproate) }\end{array}$ & $500(29-901)$ & $\begin{array}{l}\text { MR (moderate), } \\
\text { Dystonia, Epilepsy }\end{array}$ & CPS1, HoM & S: 23 y \\
\hline
\end{tabular}

ARGD: Arginase deficiency, ASLD: Arininosuccinate lyase deficiency, ASSD: Argininosuccinate synthetase deficiency, c.m.: cousins marriage, CPS1D: Carbamoyl phosphate synthetase I deficiency, D: Died, d: days, f.h.: family history of neonatal-infantile dead of own siblings or parenteral siblings, F: Female, HoM: Homozygous Mutation, M: Male, mo: months, MR: Mental Retardation, NA: Not available, NR: Normal ranges of plasma ammonia levels <80 $\mu m o l / L$, OTCD: Ornithine transcarbamylase deficiency, s.l.a.: sepsis like appearance, S: Survived, $t:$ twins, UCD: Urea cycle disorders, y: years 


\section{Clinical course}

Patients' characteristics were summarized in Table 1. Anthropometrical parameters were in the normal range, except one who was a premature newborn small for its gestational age (patient \# 4).

Median peak ammonia level for all patients was $749 \mu \mathrm{mol} / \mathrm{L}$ (range: $58-8984$ ). Of special interest, the highest peak ammonia was measured in a patient with ASLD (8984 $\mu \mathrm{mol} / \mathrm{L})$, and CPS1D (6056 $\mu \mathrm{mol} / \mathrm{L})$. The median peak ammonia level in patients with neonatal UCD was $970 \mu \mathrm{mol} / \mathrm{L}$, in late-onset UCD it was $369 \mu \mathrm{mol} / \mathrm{L}$.

Neonatal onset UCD patients was diagnosed without delay. However, in 50\% (two of four) of the patients with late- onset UCD delay of diagnosis was detected (2 years for ARGD and 3 years for CPS1D).

A hyperammonemic metabolic crisis presented as an acute life-threatening "septic" event manifested during the neonatal period in all patients with neonatal-onset UCD. After a symptoms-free interval of a few days it was reported as neonatal sepsis resembling crisis. Vomiting was reported in 4 of neonatal-onset UCD patients. Frequent hospitalizations due to hyperammonemia (acute metabolic crisis

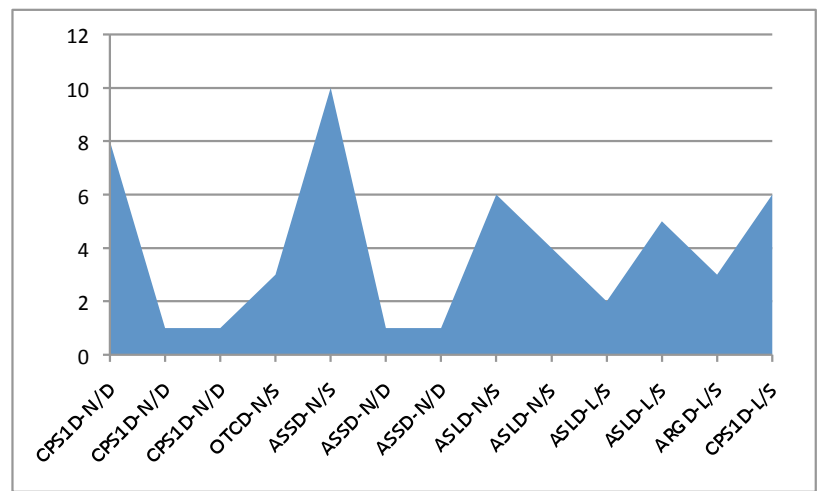

Figure 3. Distribution of hospitalization number according to the diagnosis.

Abbreviations:

ARGD: Arginase deficiency

ASLD: Arininosuccinate lyase deficiency

ASSD: Argininosuccinate synthetase deficiency

CPS1D: Carbamoyl phosphate synthetase I deficiency

D: Died

L: Late-onset

$N$ : Neonatal-onset

OTCD: Ornithine transcarbamylase deficiency

S: Survived after diagnosis) were detected in all 13 patients. The median number of hospitalizations for the patients with neonatal-onset and late-onset UCD were 2, and 3.5 days, respectively. The distribution of the number of hospitalizations according to the diagnosis and life status was shown in Figure 3.

The majority of the patients with classical UCD had neurological manifestations including mental retardation [50\% (2/4) of survived patients with neonatal-onset UCD, and $100 \%$ (4/4) of the survived patients with late-onset UCD) and seizure [50\% (2/4) of survived patients with neonatal-onset UCD, and $1 / 425 \%$ (1/4) of the patients with late-onset UCD]. The survived patients with neonatal onset UCD were less affected by mental retardation compared with late-onset UCD patients. Notably, all of the patients with late-onset UCD presented with mental retardation. Two of them (OTCD and ARG1D) never had a documented metabolic crisis. Dystonia was present in one patient with late-onset CPS1D. All patients with late-onset UCD had neurological signs and symptoms that preceded the time of crisis/diagnosis; however these were recognized only retrospectively as initial symptoms.

\section{Dietary treatment}

Evaluation of nutritional management of our classical UCD patients shown on Table 2 was divided into treatment of acute and chronic UCD. In all patients immediate withdrawal of external protein sources and intervention with hypercaloric non-protein solution was documented during the treatment of acute metabolic crisis. L-Arginine supplementation was found only in one patient during the management of acute crisis. Nitrogen scavenging medications (sodium phenylbutirate and sodium benzoate) were administrated in all patients during the hyperammonemic crisis. However, the presence of significantly elevated plasma ammonia levels resulted in the need for extracorporeal procedure in all of neonatal-onset UCD patients during the first attack.

Chronic nutritional therapy consisted of limited nitrogen intake provided by medical food made up 
Table 2. Management and treatment of patients with classical UCD.

\begin{tabular}{|c|c|c|c|c|c|c|c|c|c|}
\hline & & $\begin{array}{l}\text { Hyperammonemic } \\
\text { acute metabolic } \\
\text { crisis }\end{array}$ & $\begin{array}{c}\text { Hepatic Involvement } \\
\text { (the highest value of ALT, } \\
\text { AST (IU/L)) }\end{array}$ & Treatment & $\begin{array}{l}\text { Feeding } \\
\text { problems }\end{array}$ & Diet & $\begin{array}{c}\text { Nitrogen } \\
\text { scavenger drugs }\end{array}$ & $\begin{array}{l}\text { L-Citrulline and } \\
\text { L-Arginine }\end{array}$ & $\begin{array}{c}\text { Long term } \\
\text { Compliance }\end{array}$ \\
\hline \multicolumn{10}{|c|}{ Neonatal onset -UCD } \\
\hline 1 & CPS1D & 5 & $1031-1818$ & $\begin{array}{c}\text { HEI, SB, SP } \\
\text { PD (1) }\end{array}$ & N/G feeding & + & $\begin{array}{l}\mathrm{SB}+ \\
\mathrm{SP}+\end{array}$ & ARG+ & \pm \\
\hline 2 & CPS 1D & 1 & $95-73$ & $\begin{array}{c}\mathrm{HEI}+, \mathrm{SB}+, \mathrm{SP}+ \\
\mathrm{PD}\end{array}$ & ND & ND & ND & ND & ND \\
\hline 3 & CPS1D & 1 & $166-86$ & $\begin{array}{c}\mathrm{HEI}+, \mathrm{SB}+, \mathrm{SP}+ \\
\mathrm{PD}+\end{array}$ & ND & ND & ND & ND & ND \\
\hline 4 & ASSD & 6 & $32-55$ & $\begin{array}{c}\mathrm{HEI}+, \mathrm{SB}+, \mathrm{SP}+ \\
\mathrm{PD}+\end{array}$ & $\mathrm{N} / \mathrm{G}$ & + & $\begin{array}{l}\mathrm{SB}+ \\
\mathrm{SP}+\end{array}$ & ARG+ & \pm \\
\hline 5 & ASSD & 1 & $134-33$ & $\begin{array}{c}\mathrm{HEI}+, \mathrm{SB}+, \mathrm{SP}+ \\
\mathrm{PD}+, \mathrm{HD}+\end{array}$ & ND & ND & ND & ND & ND \\
\hline 6 & ASSD & 1 & $135-49$ & $\begin{array}{c}\mathrm{HEI}+, \mathrm{SB}+, \mathrm{SP}+ \\
\mathrm{PD}+\end{array}$ & ND & ND & ND & ND & ND \\
\hline 7 & ASLD & 1 & $131-71$ & $\begin{array}{c}\mathrm{HEI}+, \mathrm{SB}+, \mathrm{SP}+ \\
\mathrm{HD}+\end{array}$ & No & + & $\mathrm{SB}+, \mathrm{SP}+$ & ARG+ & \pm \\
\hline 8 & ASLD & 1 & $31-27$ & $\begin{array}{c}\mathrm{HEI}+, \mathrm{SB}+, \mathrm{SP}+ \\
\mathrm{PD}+\end{array}$ & No & + & $\mathrm{SB}+, \mathrm{SP}+$ & ARG+ & - \\
\hline 9 & ASLD & 1 & $34-23$ & $\begin{array}{c}\mathrm{HEI}+, \mathrm{SB}+, \mathrm{SP}+ \\
\text { ARG+ } \\
\mathrm{HDF}+ \\
\end{array}$ & No & + & $\mathrm{SB}+, \mathrm{SP}+$ & ARG+ & \pm \\
\hline \multicolumn{10}{|c|}{ Late onset -UCD } \\
\hline 10 & OTCD & 0 & $244-620$ & - & No & + & $\mathrm{SB}+$ & ARG+ & \pm \\
\hline 11 & ASLD & 1 & $21-28$ & $\begin{array}{c}\mathrm{HEI}+, \mathrm{SB}+, \mathrm{SP}+ \\
\mathrm{PD}+\end{array}$ & No & + & $\mathrm{SP}+$ & ARG+ & + \\
\hline 12 & ARGD & 0 & $19-42$ & - & No & + & $\mathrm{SB}+, \mathrm{SP}+$ & - & - \\
\hline 13 & CPS 1D & 1 & $52-61$ & $\begin{array}{c}\mathrm{HEI}+, \mathrm{SB}+, \mathrm{SP}+ \\
\mathrm{HDF}+\end{array}$ & No & + & $\mathrm{SB}+, \mathrm{SPH}+$ & ARG+ & \pm \\
\hline
\end{tabular}

(-): Poor compliance to dietary treatment and medications, (+): Good compliance to dietary treatment and medications, ( \pm ): Partial compliance to dietary treatment and medications, ARG: L-Arginine, ARGD: Arginase deficiency, ASLD: Arininosuccinate lyase deficiency, ASSD: Argininosuccinate synthetase deficiency, CIT: L-Citrulline, CPS1D: Carbamoyl phosphate synthetase I deficiency, HD: Hemodialysis, HDF: Hemodiafiltration, HEI: High Energy Intake, ND: Neonatal Death, No: No feeding problems/No compliance, OTCD: Ornithine transcarbamylase deficiency, PD: Peritoneal dialysis, SB: Sodium Benzoate, SP: Sodium Phenylbutirate

Number of extracorporeal procedure was given in brackets.

primarily of essential amino acids and oral nitrogen scavengers in all survived patients with classical UCD. Recommended ranges of protein intake in the chronic setting were calculated according to different rages and growth rate for all patients. Apart from patient with ARGD, L-arginine was supplemented in all patients during the chronic treatment.

Good compliance to dietary treatment and medication was observed only in one patient with late- onset UCD (11\%), while partial, and insufficient compliance rates were detected in $66 \%(n=6)$, and 23 $\%(\mathrm{n}=2)$ of the patients with neonatal-onset UCD.

\section{Mortality}

Of all 13 patients, 5 (38\%) had died (3 patients by CPS1D ) and ASSD (2 patients)). The mortality rate in neonatal onset cases was $56 \%$, and $0 \%$ in late onset cases. The mortality in neonatal onset disease was 
greatest in CPS1D followed by ASSD. All of the neonatal cases presented as ASLD patients survived.

\section{DISCUSSION}

The aim of this study was to describe and evaluate the clinical presentations of patients with UCD. Consistent with the literature we found that the infants with classical UCD were presented mainly during neonatal period ${ }^{(4,5)}$.

Regarding distribution of the USD according to the enzyme deficit it was interesting to see that the most common disorders were CPS1D and ASLD. Notably, only one patient with OTCD was detected. However OTCD is the most common UCD, with an estimated incidence of 1 in $14.000^{(6)}$. Confirming data from other reports elucidated that as clinical awareness of these disorders has grown, the number of patients presenting and being diagnosed with lateonset UCD increased. OTCD was generally lateonset UCD, so when OTCD patients were excluded, our study population was in line with published data (4). Here we need to underline that possible diagnostic neglect is worrying albeit similar to other inborn errors of metabolism previously reported ${ }^{(4-7)}$. Periods of decompensation associated with neurological abnormalities were clues for consideration of UCD.

\section{Neonatal-onset UCD}

The main presentation pattern of our classical neonatal-onset UCD patients was critically high blood levels of ammonia in combination with "sepsis like appearance". In the neonatal period symptoms and signs are mostly related to brain dysfunction due to the hyperamommonemia, vomiting, tachypnea and lethargy which quickly progress to a deep coma. Therefore, at the beginning, measurements of ammonia level is indicated in cases with potential UCD ${ }^{(3)}$. With confirmatory data from other reports, this study demonstrated that neonatal onset UCD manifests septic symptoms with main predominance of hyperammonemia (ammonia levels greater than 500 $\mu \mathrm{mol} / \mathrm{L})^{(8)}$. In consideration of the fact that neonatal- onset UCD is related to the effect of striking hyperammonemia on the body, most prominently being dysfunction of the liver and alterations in mental status leading to "septic" coma, this is an important outcome

Our data did not reveal evidence of intrauterine disease manifestation or increased maternal health problems in pregnants with UCD which is in line with previous reports ${ }^{(5)}$. As it was expected the patients were normal at birth and become symptomatic within a few days of protein feeding. The prevention of accumulation of toxic metabolites in fetus with UCD by the action of maternal placenta could be an explanation for the fact that the first symptoms should not occur before the newborn period.

As demonstrated earlier, nearly all of our patients with neonatal-onset UCD were symptomatic and diagnosed before the first week ${ }^{(5)}$. The neonatal onset of symptoms was thought to reflect severe disease course because of low residual enzyme activity ${ }^{(9,10)}$.

Interestingly, ASSD was only observed as neonatal presentation. This is an important result since knowing about the fact that ASSD was the predominantly reported UCD presented during neonatal period by Spanish national study ${ }^{(11)}$.

The neonatal-onset UCD had the poorest survival rate in our study. The similar high mortality rates in patients presenting with a metabolic crisis in newborn period were reported by other studies ${ }^{(4,9,10,12)}$. This is the reason why UCDs are commonly considered as diseases of catastrophically ill neonates. The underlying molecular defects in patients with neonatal onset UCD at the beginning of the urea cycle tend to be more severe, because blockade in first steps of the process occurs before any nitrogen is pulled into the cycle of intermediates.

\section{Late Onset UCD}

In recent years it has become obvious that nonclassical UCD patients with late onset and/or an attenuated clinical course may be as frequent seen as those with classical presentations during the first week of life ${ }^{(13)}$. However, reviewing our data records 
we found that our late-onset UCD patients were less than half of the neonatal patients with UCD. Most frequently these patients developed neurological symptoms such mental retardation, seizures and movement disorders. Affected older children in this study were presented with vomiting and neurological abnormalities (ataxia, agitation, irritability, mental confusion and combativeness).

These comorbid conditions associated with a broad spectrum of differential diagnoses led to delay or even miss in diagnosis. Based on confirmatory data obtained from other reports ${ }^{(13,14)}$ neurological symptomatology was presented in all of patients with late-onset UCD. This is why when a seemingly "healthy" but indeed affected individual may have few or no symptoms to indicate an underlying diagnosis. Often the diagnosis becomes apparent during increased metabolic stress, such as acute-chronic illness or immunization, influenza, trauma, surgery. The later onset of symptoms and altered clinical presentation associated with partial enzyme activity can often lead to delayed recognition of UCD, delayed treatment and emergence of prominent neurological findings. Therefore, the diagnosis should be made as early as possible to avoid neurological complications.

\section{TREATMENT}

There are some independent principles in the management of hyperammonemic coma: physical removal of the ammonia by dialysis or hemofiltataion; reversal of catabolic state through caloric supplementation and pharmacologic scavenging of excess nitrogen. Frequent hospitalizations detected in both neonatal and late onset UCD generally depends on the exposure of the patients to the triggering factors. Cold and illness can be critical triggers in young children. The high number of hospitalizations reported in this study demonstrated the urgent requirement of sick-day diet regimen with additional energy for the days before and following physiological (dentination, menstruation etc.) or medical events.

Dietary nonadherence can certainly contribute to metabolic instability and a tool such as a 3-day diet history may be helpful in uncovering the problem. A combination of factors, including inadequate patient and family understanding of complex treatment regimens, economic stressors, difficulties in balancing the resources and efforts required by special needs of the child with the rest of the family's demands, and sheer fatigue on the part of the caregivers from the burden of dealing with chronic illness can contribute adversely to compliance to treatment. Social service and professional counseling support is imperative and should be engaged early in the treatment plan.

Preventing peripheral breakdown-catabolic stressis our main principle during the chronic treatment of patients with UCD, because it is even more important than controlling dietary nonadherence for avoiding decompensation in the management of patients with UCD. Recent studies show that nitrogen is more efficiently incorporated into urea when it is from enteral rather peripheral sources ${ }^{(15)}$.

The present study has some limitations. In the present context we did not include the patients with underdiagnosed hyperammoniemia inthe study. Besides duration of hyperammonaemia, and timing with variations in the treatment were not taken into consideration. Particularly in nenatal-onset UCD patients, time and clinical phenotype at the start of treatment is of utmost importance.

\section{CONCLUSION}

The clinical presentation of classical UCD is nonspecific including sepsis-like appearance during hyperammonemic crisis in the newborn period and mental retardation, seizures and movement disorders in the late-onset patients. To improve the outcomes of this disease, it is important to further increase the awareness of physicians about these rare diseases. Therefore establishment of local or national programmes that will allow early identification of affected individuals and supply teams with experienced members for the follow-up of the patients carry utmost importance. 


\section{ACKNOWLEDGEMENT}

The authors are grateful to Dr. J. Haberle and Dr. S. Ceylaner for their excellent support in organizing and performing the genetic analysis. The authors further acknowledge the excellent support given by pediatric nephrologists, neurologists and dietitians during the multidisciplinary follow-up of the patients.

\section{REFERENCES}

1. Zschocke J, Hoffmann GF. Vademecum metabolicum, diagnosis and treatment of inborn errors of metabolism, 3rd ed., Schattauer, 2014, p.57-60.

2. King LS, Singh RH, Rhead WJ, Smith W, Lee B, Summar MS, Genetic counseling issues in urea cycle disorders, Crit Care Clin 2015;21:37-44. http://dx.doi.org/10.1016/j.ccc.2005.08.001

3. Haberle J, Rubio V. Hyperammonemias and related disorders. In Blau N, Duran M, Gibson KM, Dionisi-Vici C (eds.),Spriger , Heidelberg, 2014; p.47-63. http://dx.doi.org/10.1007/978-3-642-40337-8_4

4. Summar ML, Dobbelaere D, Brusilow S, Lee B. Diagnosis, symptoms, frequency and mortality of 260 patients with urea cycle disorders from a 21-year, multicentre study of acute hyperammonaemic episodes. Acta Paediatr 2008;97(10): 1420-1425. http://dx.doi.org/10.1111/j.1651-2227.2008.00952.x

5. Kölker S, Cazorla AG, Valayannopoulos V, Lund AM, Burlina AB, Sykut-Cegielska J, et al. The phenotypic spectrum of organic acidurias and urea cycle disorders. Part 1: the initial presentation. J Inherit Metab Dis 2015;38(6):10411057. http://dx.doi.org/10.1007/s10545-015-9839-3

6. Brusilow SW, Mastri NE. Urea cycle disorders: diagnosis, pathophysiology, and therapy. Adv Pediatr 1996;43:127170 .
7. Rowe PC, Newman SL, Brusilow SW. Natural history of symptomatic partial ornithine transcarbamylase deficiency. $N$ Engl J Med 1986;314(9):541-547. http://dx.doi.org/10.1056/NEJM198602273140903

8. Nakamura K, Kido J, Mitsubuchi H, Endo F. Diagnosis and treatment of urea cycle disorder in Japan. Pediatr Int. 2014;56(4):506-509. http://dx.doi.org/10.1111/ped.12439

9. Nassogne MC, Héron B, Touati G, Rabier D, Saudubray JM. Urea cycle defects: management and outcome. J Inherit Metab Dis 2005;28(3):407-414. http://dx.doi.org/10.1007/s10545-005-0303-7

10. Enns GM, Berry SA, Berry GT, Rhead WJ, Brusilow SW, Hamosh A. Survival after treatment with phenylacetate and benzoate for urea-cycle disorders. N Engl J Med 2007 31;356(22):2282-2292.

11. Martín-Hernández E, Aldámiz-Echevarría L, Castejón-Ponce E, Pedrón-Giner C, Couce ML, Serrano-Nieto J, et al. Urea cycle disorders in Spain: an observational, cross-sectional and multicentric study of 104 cases. Orphanet J Rare Dis 2014;9:187 http://dx.doi.org/10.1186/s13023-014-0187-4

12. Burgard P, Kölker S, Haege G, Lindner M, Hoffmann GF. Neonatal mortality and outcome at the end of the first year of life in early onset urea cycle disorders-review and metaanalysis of observational studies published over more than 35 years. J Inherit Metab Dis 2015 Dec 3 PMID: 26634834

13. Rüegger CM, Lindner M, Ballhausen D, Baumgartner MR, Beblo S, Das A, et al. Cross-sectional observational study of 208 patients with non-classical urea cycle disorders. J Inherit Metab Dis 2014;37(1):21-30. http://dx.doi.org/10.1007/s10545-013-9624-0

14. Kölker S, Valayannopoulos V, Burlina AB, Sykut-Cegielska J, Wijburg FA, Teles EL, et al. The phenotypic spectrum of organic acidurias and urea cycle disorders. Part 2: the evolving clinical phenotype. J Inherit Metab Dis 2015;38(6):10591074. http://dx.doi.org/10.1007/s10545-015-9840-x

15. Scaglia F, Marini J, Rosenberger J, Henry J, Garlick P, Lee $\mathrm{B}$,et al. Differntial utilization of systemic and enteral ammonia from urea synthesis in control subjects and ornithine transcarbamylase defiecncy carriers. Am J Clin Nutr 2003;78 (4):749-755. 